\title{
Numerical simulation of roof bolt system during depillaring operation in bord and pillar panel
}

\author{
Rizwan Hasim, Ashok Jaiswal and BK Shrivastva \\ Indian Institute of Technology (BHU) \\ Varanasi, India \\ riz.itbhu@gmail.com
}

\author{
Satyabdi Jena \\ South Eastern Coalfield Limited \\ Bilaspur, India
}

\begin{abstract}
Roof bolting technology is widely used for support design in an underground coal mine. This paper focused on the numerical simulation considered the behaviour of roof and rock - grout - bolt interaction. Simulation of three dimensional model of depillaring panel with roof bolt support is difficult to simulate. Therefore, an analogy has been developed to replicate three dimensional depillaring panel into two dimension considered physico-mechanical properties of the immediate roof, geotechnical property of the mine and bolt and grout properties as an input parameters. A case of depillaring panel has been chosen for study. The simulation of rock bolt gives the result in terms of axial load developed on the bolt with depillaring panel advancement. Field observation of instrumented rock bolt has taken for validation of the numerical model. It has been observed that the maximum load developed on the model is very close to the field data.
\end{abstract}

Keywords-Bord and Pillar; depillaring panel; full column grout rock bolts; instrumented rock bolt; three-dimensional simulation

\section{INTRODUCTION}

Presently, the trend of Indian underground coal mine is going into mechanizationusing continuous miner technology in Bord and Pillar working. The machine has operated in wider gallery size around $6 \mathrm{~m}$ to $6.5 \mathrm{~m}$ during development stage, due to smooth maneuvering of the machine and fast retreating during depillaring stage.In conventional method of mining LHD/SDL machine has been used to operate the gallery size upto $4.8 \mathrm{~m}$. The present practices on support design considering two major parameters such as Rock Mass Rating (RMR) and gallery size and it has been designed for conventional mining method.There have no as such support design guideline has available for wider gallery operation in mechanized mining technology. As per existing Director General of Mine Safety guidelines, systematic support rules must be followed at the depillaring faces irrespective of immediate roof rock type and competency. There are two types of support system are used in underground Bord and Pillar mining named as active and passive. Cog, chock, props are falling into the category of active support while rock bolt is a passive type, utilizing the rock strength by applying internal reinforcing stresses. Rock bolt are very much popular globally as well as in India. Number of research has been done in support design in the form of mathematical and empirical calculation.
The three-dimensional numerical simulation gives the reasonable understanding to analyze the complex roof strata and bolt interaction.

\section{OBJECTIVE}

In this study, an attempt has been made to analyze the roof bolting system under depillaring operation by numerical simulation method. Axial load on the bolt and roof behavior has been analyzed and understand.

\section{SITE DETAILS}

A mine - A working with Bord and Pillar mining using continuous miner technology has been chosen for study. The mine has developed by conventional mining with SDL/LHD of 5 heading panels having gallery width $4.8 \mathrm{~m}$ and pillar size $21.2 \mathrm{~m}$ corner to corner. The depth of working varies from $104 \mathrm{~m}$ to $120 \mathrm{~m}$. The depillaring operation has been carried out by continuous miner technology. Gallery size has been widening

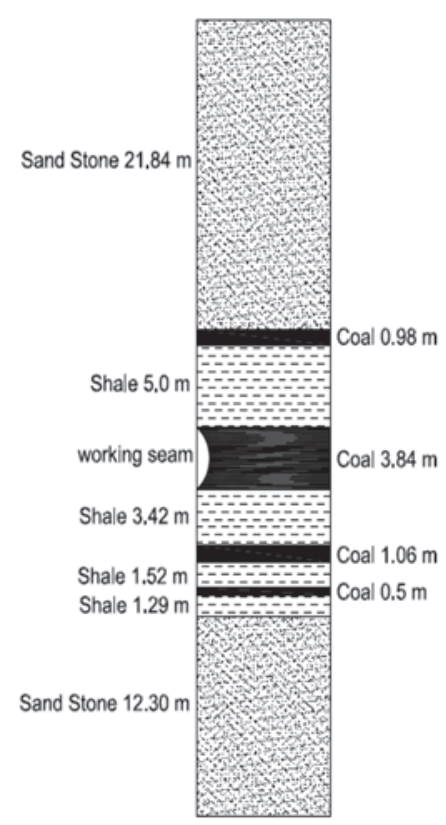

Fig.1. Borehole cross - section (not to scale)

from $4.8 \mathrm{~m}$ to $6.5 \mathrm{~m}$ for smoother operation of continuous miner technology.This result intoreduced the pillar size 
$19.5 \mathrm{~m}$ from actual size $21.2 \mathrm{~m}$. The thickness of working seam varies from $3.0 \mathrm{~m}$ to $4.0 \mathrm{~m}$ and height of working has $2.8 \mathrm{~m}-3.0 \mathrm{~m}$ borehole cross section shown in Fig. 1 leaving $0.5 \mathrm{~m}$ of coal in the roof due to $5.0 \mathrm{~m}$ thick massive shale just above the coal seam. Panel - 6 has been chosen for study, shows the detailed plan in Fig. 2 this consists of 48 numbers of pillars has to be extracted in depillaring operation.

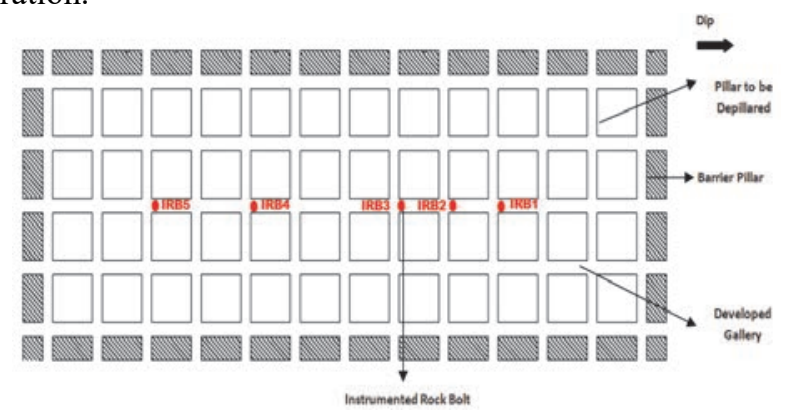

Fig.2.Development Panel 6 of Mine - A

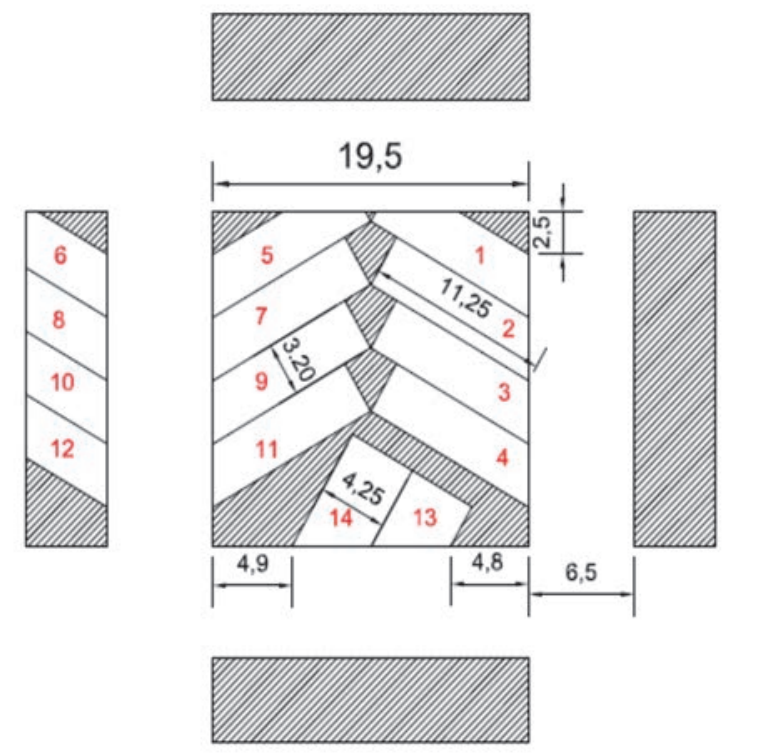

Fig.3.Extraction pattern of Pillar by Continuous Miner

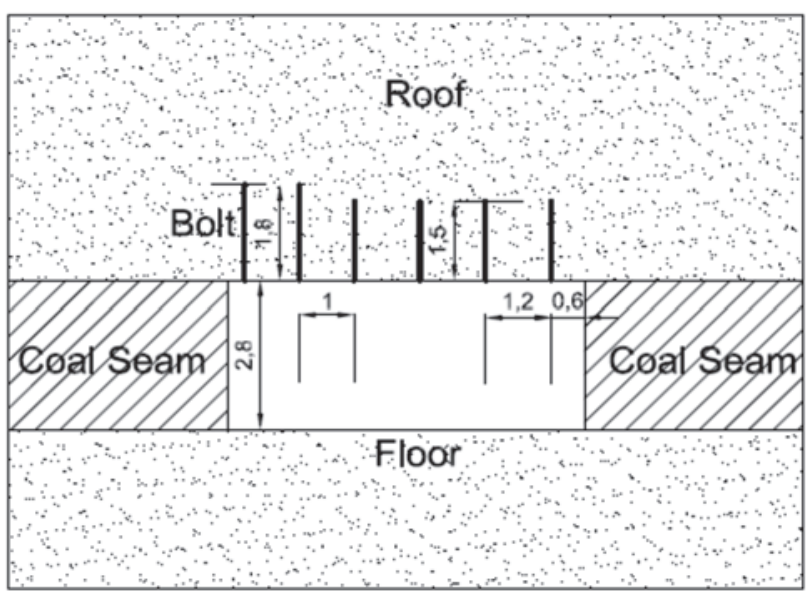

Fig.4. Existing support system in Gallery

\section{FIELD INSTRUMENTATION}

Instrumented rock bolt is the monitoring device having numbers of strain gauges installed in the bolt. This will be used to get the value of axial load and bending moment. Instrumented rock bolts having 18 gauges (9 left and right side) has been installed in mineas shown in Fig. 5. Five instrumented rock bolts named (IRB1, IRB2, IRB3, IRB4, and IRB5) of length $2.4 \mathrm{~m}$ were installed vertically in the immediate roof strata at five selected position of the level galleries in the panel as shown in Fig. 2.

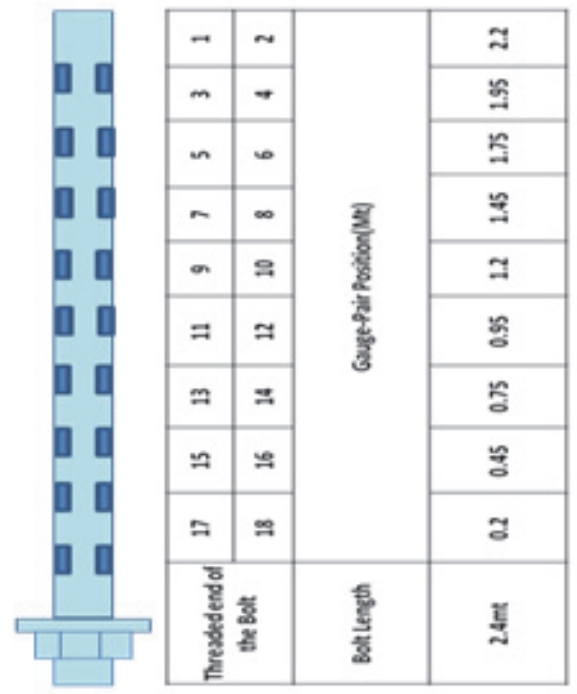

Fig.5.Instrumented rock bolt

\section{FIELD OBSERVATION}

In this mine, the general trend of major fall occurs after 2 to 3 pillar has extracted. So, the time of installation of instrumented bolt, when the working face was 2 to 3 pillar away. The observation has continued till the goaf edge reached near the instrumented bolt. The maximum load occurredin the range of 0.25 tonne to 1.10 tonne ondifferent instrumented bolt installed in the panel.It has been observed that the maximum loadon each bolt was approximately 1.5 $\mathrm{m}-2.0 \mathrm{~m}$ from the roof level.

\section{VI.NUMERICAL MODELING}

\section{A. Methodology}

It has been observed by field observationand numerical simulation [1] that the induced stress on the pillar increases with the advancement of goaf. In the case of depillaring operationthree - dimensional simulation of the whole panel with rock bolting is very difficult, because it has take more computational time to solve. So, to overcome such problem an analogy has been developed to replicate threedimensional depillaring panel into a two-dimension section of the panel. The plan view of section of two - dimensional model shown in Fig. 6 (a) and the two - dimensional discretizational view of the model is shown in Fig. 6 (b). It has been analyzed that the load on the model continuously 
increasing with the advancement of the goaf edge and it will reach maximum value $7.87 \mathrm{MPa}$ shown in Table 1 when the goaf edge near to the model. The width of the model taken into consideration is row spacing. Themaximum induce stress has been calculated with the help of following empirical equation. [1]

$$
\mathrm{Su}=0.025 \mathrm{H}+\frac{8.646}{10000} \mathrm{H} \sqrt{ } \mathrm{I} \mathrm{MPa}
$$

where, $\mathrm{Su}=$ ultimate induced stress

$\mathrm{I}=$ capability index and

$\mathrm{H}=$ average cover depth of coal seam.

Cavability index has taken in this case $=2208$ [1]

TABLE I AXIAL LOAD ON ROCK BOLT IN DIFFERENT STAGES OF MINING

\begin{tabular}{|l|c|c|c|}
\hline \multirow{2}{*}{ Mining Stages } & \multirow{2}{*}{$\begin{array}{c}\text { Total } \\
\text { Stress } \\
\text { (MPa) }\end{array}$} & $\begin{array}{c}\text { Instrumented } \\
\text { Rock bolt } \\
\text { result_IRB1 } \\
\text { (Field) }\end{array}$ & $\begin{array}{c}\text { Instrumented } \\
\text { Rock bolt } \\
\text { result } \\
\text { (Simulation) }\end{array}$ \\
\hline Development stage & & 0.2 & 0.25 \\
\hline Depillaring Stage & & & \\
\hline Stage 1 & 5.87 & - & 0.45 \\
\hline Stage 2 & 6.37 & - & 0.49 \\
\hline Stage 3 & 6.87 & - & 0.54 \\
\hline Stage 4 & 7.37 & - & 0.58 \\
\hline Stage 5 & 7.87 & 0.55 & 0.61 \\
\hline
\end{tabular}

Now, the steps involved to simulate the rock bolt in twodimension section of the panel has described below:In the first step, model has been simulated in development stage to evaluate the response of roof behavior and rock-bolt-grout interaction.

In the next step, model has been simulated in depillaring stage. The maximum induced stress was developed when the goaf edge reached near to the model and in between there are numbers of stages have been simulated named as mining stage 1 to 5 shown in Table 1 for their subsequent value of induced stress. Table 1 also shows the different value of the axial load on the bolt in different mining stages

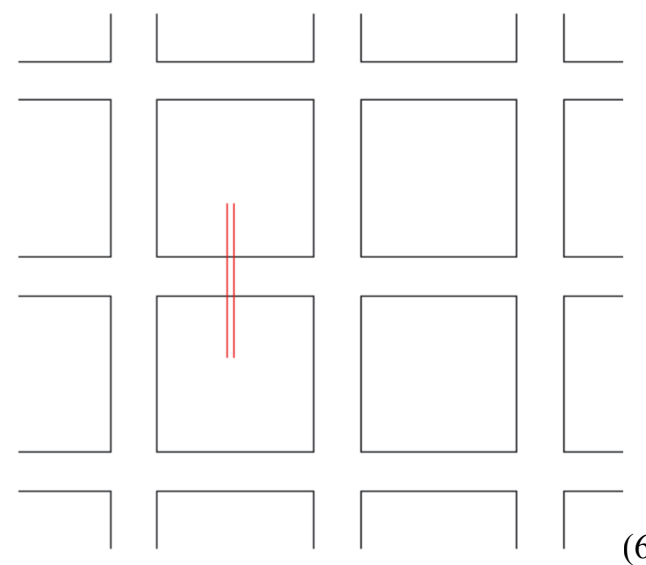

(6a)

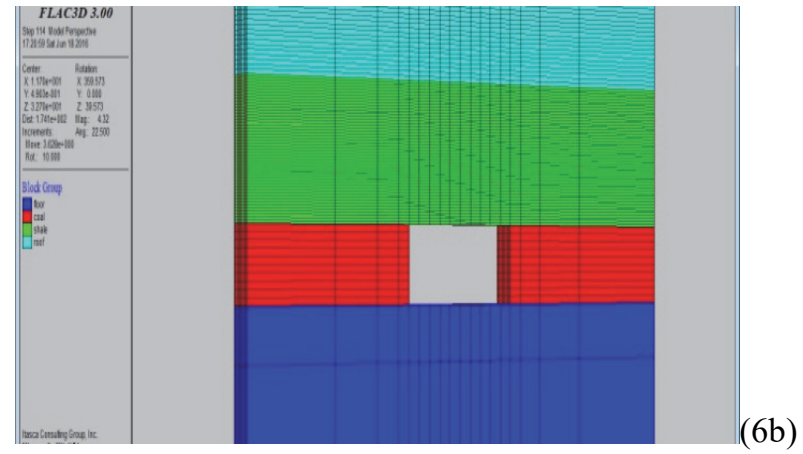

Fig.6 (a). Plan view of section of two-dimensional model; Fig.6 (b).Discretizational view of the model

\section{B. Model geometry}

The discretizational view of the modelconsisted four numbers of layers containing floor, coal, shale (immediate roof), and roof. The dimension of the global model of a section of the panel is $26.0 \mathrm{~m}$ in width, $1 \mathrm{~m}$ long and $62.8 \mathrm{~m}$ in height. The discretization is more in the gallery where the bolt has installed and less on the pillar because the focus is to interpreted the behavior of the rock bolt with rock mass and grout in the gallery. Grid pattern in $\mathrm{x}, \mathrm{y}$ and z-direction in the pillar are 5, 10 and 10 and in the gallery, it is 50,10 and 50.

\section{Boundary Condition}

Since the depth of cover of the coal seam is around $120 \mathrm{~m}$ and our model height is around $30.0 \mathrm{~m}$ from the coal seam. So, vertical stress of $3.00 \mathrm{MPa}$ has applied to the top of the model, which has calculated by using the formula in equation 2 with gravity loading, while the horizontal stress has calculated as $2.03 \mathrm{MPa}$ by using the formula in equation 3 oriented along $\mathrm{X}-\mathrm{X} \& \mathrm{Y}-\mathrm{Y}$ direction. The boundary condition assigned to the sides, top and bottom of the global model have fixed.

\section{Assighning Material Properties}

An elastic model was used to simulate the rock strata except for immediate roof strata i.e. shale.It has been considered as strain softening material in the model.In - situ vertical stress can be written as

$$
\sigma_{\mathbf{v}}=\rho g H
$$

And, using Sheorey formula the value of horizontal stress [10]

$$
\sigma_{\mathrm{h}}=\sigma_{\mathrm{v}} \frac{\mathrm{v}}{1-\mathrm{v}}+\frac{\beta E G}{1-\mathrm{v}}(\mathrm{H}+1000)
$$

where,

$\sigma_{\mathrm{v}}=$ vertical stress inMPa

$\mathrm{H}=$ depth in $\mathrm{m}$

$\boldsymbol{\rho}=$ average density in $\mathrm{t} / \mathrm{m}^{3}$

$\mathrm{g}=$ acceleration due to gravity in $\mathrm{m} / \mathrm{s}^{2}$

$\sigma_{\mathrm{h}}=$ horizontal stress in $\mathrm{MPa}$

$v=$ poission's ratio

$\boldsymbol{\beta}=$ is the coefficient of thermal expansion in $/{ }^{\circ} \mathrm{C}$

$\mathrm{E}=$ Young's Modulus in $\mathrm{MPa}$ 


$$
\mathrm{G}=\text { is the thermal gradient }{ }^{\circ} \mathrm{C} / \mathrm{m}
$$

Table II shows the physico-mechanical properties of rock coal; Table 3 and Table 4 shows the rock, coal, properties used in the numerical model. The Sheorey failure criteria has been used to calculate the properties used in the model. [5]

TABLE II PHYSICO-MECHANICAL PROPERTIES OF THE ROCK STRATA

\begin{tabular}{|l|c|c|c|c|c|}
\hline $\begin{array}{c}\text { Rock } \\
\text { Type }\end{array}$ & $\begin{array}{c}\text { Modulus E, } \\
\text { (MPa) }\end{array}$ & $\begin{array}{c}\text { Poisson's } \\
\text { Ratio }\end{array}$ & $\begin{array}{c}\text { Density } \\
\text { (kg/m3) }\end{array}$ & $\begin{array}{c}\text { UCS } \\
\text { MPa }\end{array}$ & $\begin{array}{c}\text { Tensile } \\
\text { Strength } \\
\text { MPa }\end{array}$ \\
\hline Shale & 4000 & 0.41 & 2270 & 24.50 & 1.64 \\
\hline Sandstone & 1000 & 0.31 & 1970 & 32.50 & 2.17 \\
\hline Coal & 4000 & 0.27 & 1350 & 20.50 & 1.37 \\
\hline
\end{tabular}

TABLE III GEO-TECHNICAL PROPETIES FOR THE NUMERICAL MODEL

\begin{tabular}{|c|c|c|c|c|c|}
\hline $\begin{array}{c}\text { Rock } \\
\text { Strata }\end{array}$ & $\begin{array}{c}\text { Thickness } \\
\text { (m) }\end{array}$ & $\begin{array}{c}\text { Shear } \\
\text { Modulus } \\
\text { (GPa) }\end{array}$ & $\begin{array}{c}\text { Bulk } \\
\text { Modulus } \\
\text { (GPa) }\end{array}$ & $\begin{array}{c}\text { Friction } \\
\text { angle } \\
\text { (degree) }\end{array}$ & $\begin{array}{c}\text { Cohesion } \\
\text { (MPa) }\end{array}$ \\
\hline $\begin{array}{c}\text { Top } \\
\text { Layer }\end{array}$ & 30 & 1.98 & 3.47 & 40 & 10.0 \\
\hline Coal & 3.0 & 1.57 & 2.89 & 40 & 5.0 \\
\hline $\begin{array}{c}\text { Bottom } \\
\text { Layer }\end{array}$ & 30 & 1.90 & 4.38 & 40 & 10.0 \\
\hline
\end{tabular}

TABLE IV GEO-TECHNICAL PROPERTIES OF IMMEDIATE ROOF

\begin{tabular}{|c|c|c|c|c|}
\hline $\begin{array}{c}\text { Rock } \\
\text { Strata }\end{array}$ & $\begin{array}{c}\text { Friction } \\
\text { angle } \\
\text { (degree) }\end{array}$ & $\begin{array}{c}\text { Cohesion } \\
\text { (MPa) }\end{array}$ & $\begin{array}{c}\text { Dilation } \\
\text { angle } \\
\text { (degree) }\end{array}$ & RMR \\
\hline $\begin{array}{c}\text { Roof } \\
\text { Strata } \\
\text { (Shale) }\end{array}$ & 25 & 1 & 0 & 52 \\
\hline
\end{tabular}

After the development, there might be some yield zones formed in the roof on the entry. To cover this essential process $5.0 \mathrm{~m}$ rock (shale) in the immediate roof was simulated as strain-softening material considering the effect of weak planes or joints on the rock-mass strengths. The rockbolt has been considered as linear element.

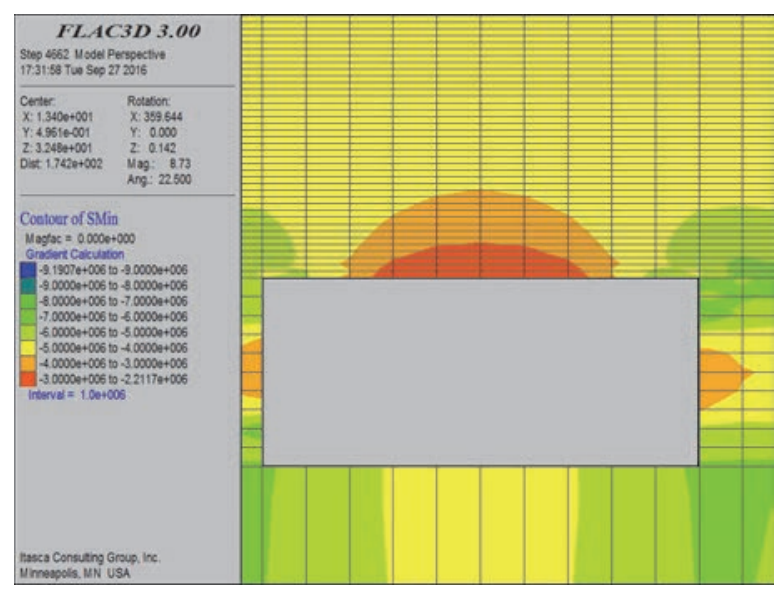

Fig.7. Maximum principle stress in development stage with roof bolt

\section{RESULTS AND DISCUSSIONS}

The stress distribution of model while installing roof bolts after development work has done is shown in Fig. 7. The axial load exerted on roof bolt is shown in Fig. 8 which is 0.25 tonne.In depillaring stage there are 5 numbers of model are simulated the results have shown in Table 1 and graph in Fig. 10.

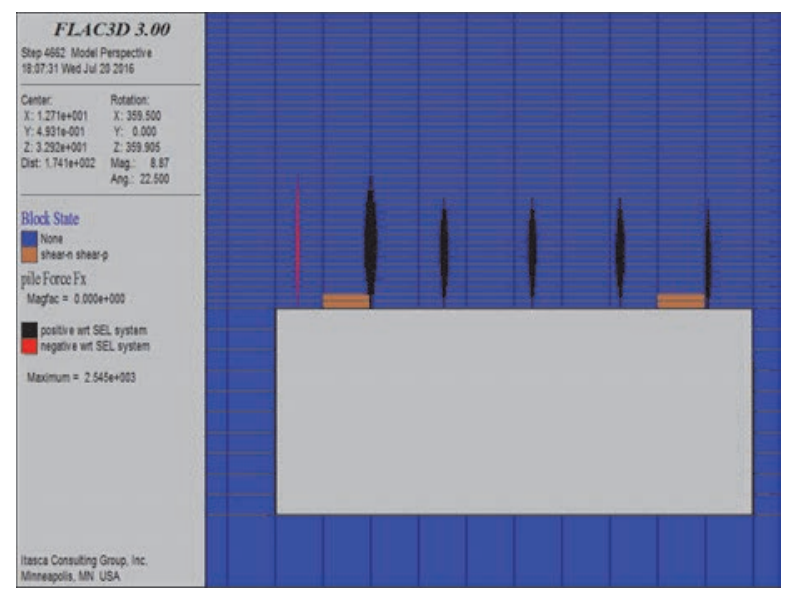

Fig.8.Axial load on bolt in development stage

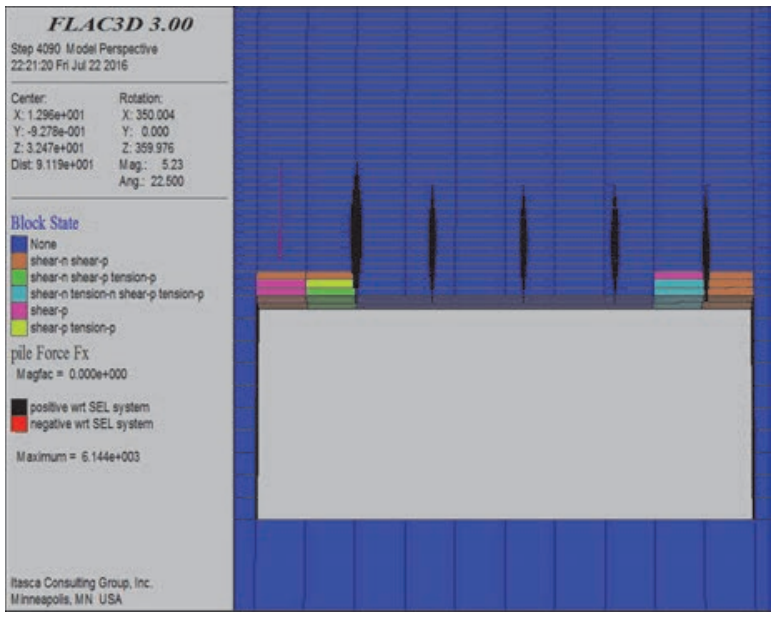

Fig. 9.Axial load in depillaring stage ( $5^{\text {th }}$ Stage)

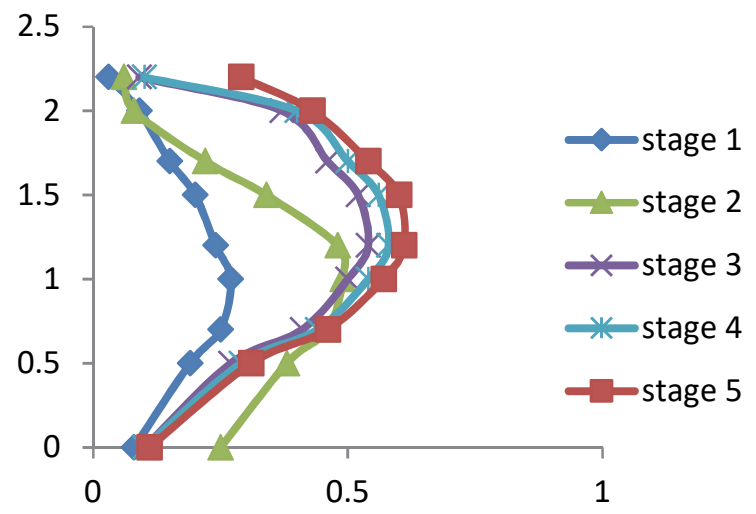

Fig. 10.Shows axial load in different depillaring stages 
The maximum axial load exerted on the rock bolt is shown in the $5^{\text {th }}$ stage where the induce stress is maximum shown in Fig.9and least value of axial load has been observed in $1^{\text {st }}$ stage. The field instrumentation results indicated maximum axial load in instrumented rock bolt IRB 1 is 0.55 tonne and from the model results the maximum axial load shows in $5^{\text {th }}$ stage is 0.61 tonne, therefore it has been observed that the model has validate with the field observation.

\section{CONCLUSION}

The 3D numerical model results indicate that during development stage the axial load on rock bolt is 0.25 tonnes. In depillaring stage it has been observed, with advancement of goaf edge the value of induced stress and axial load occurred on the bolt increases. The maximum value of induced stress has been observed as $7.87 \mathrm{MPa}$ and axial load on bolt is 0.61 tonne.

The similar conclusion has also obtained when comparing the axial load on roof bolts between the modelpredicted and field-monitored results. In other words, the proposed three-dimensional roof bolt model has enough accuracy to simulate its behavior.

Also, it has found that the roof bolts can significantly increase the stiffness of surrounding rocks. It helps to understand that why the roof bolts can reduce the roof sag in underground entries.

\section{REFERENCES}

[1] Prasoon Garg and Ashok Jaiswal, Estimation of Modulus of the Caved Rock for Underground Coal Mines by BackAnalysis using Numerical Modelling, Journal of Institute of Engineers, 2015.

[2] Jingyi Cheng, Wenfeng Li and Zhijun Wan Development and Calibration of a 3D Numerical Modeling of Roof Bolts - A Case Study

[3] B.H.G. Brady, E.T.Brown, Rock Mechanics for underground mining Third Edition 224-235,2004.

[4] Abdolreza Osouli, Iman Shafii Roof Rockmass Characterization in an Illinois Underground Coal Mine, (25 March 2016)

[5] A. Kushwaha, S.K.Singh, S.Tewari, A.Sinha Empirical approach for designing of support system in mechanized coal pillar mining in Int. J. Rock Mech. Min. Sci (8 June 2010)

[6] Ghadimi Mostafa, Shahriar Kourosh, Jalalifar Hossein Analysis profile of the fully grouted rock bolt in jointed rock using analytical and numerical methods in Int. J. Rock Mech. Min. Sci., 2014.

[7] S. Sinha, Yoginder P. Chugh, An evaluation of roof support plans at two coal mines in Illinois usingnumerical models in Int. J. Rock Mech. Min. Sci., 2015

[8] Heritage Yvette, Stemp Craig, A combined 2D and 3D numerical modeling approach to provideadequate roof support in complex 3D excavations in Int. J. Rock Mech. Min. Sci, 2015

[9] Tin Nguyen, Kazem Ghabraie , Thanh Tran-Cong Simultaneous pattern and size optimisation of rock bolts for underground excavations in Computers and Geotechnics Elsevier, 2015.

A Kushwaha and G Banerjee. Exploitation of developed coal mine pillars by shortwall mining-a case example. Int J Rock Mech Min Sci 2005;42: pp127-36. 